Original Article

\title{
Pouteria ramiflora leaf extract on emulgel in wound healing activity in diabetic rats
}

\author{
Ação do extrato de folhas de Pouteria ramiflora em emulgel na atividade de \\ cicatrização de feridas em ratos diabéticos
}

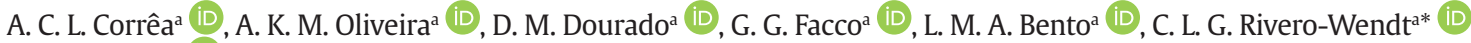 \\ and R. Matias ${ }^{\mathrm{a}}$ \\ a Universidade Anhanguera - UNIDERP, Programa de Pós Graduação em Meio Ambiente e Desenvolvimento, Campo Grande, MS, Brasil
}

\begin{abstract}
The genus Pouteria has been studied because it presents various activities, among which is its anti-inflammatory potential. The effects of Pouteria ramiflora Carbopol gel on the healing of skin wounds in diabetic rats were evaluated by microscopic imaging. Streptozotocin was administered intraperitoneally in animals that had fasted for 12 hours, a situation confirmed by the glycemic index $\left(>240 \mathrm{mg} \mathrm{dL}^{-1}\right)$. An excision on the back of the animals was performed and three groups were formed: Control (Gel), Ethanolic extract (Ext) and Gel + extract 2\% (Ext+gel); the histopathological evaluation occurred on the $7^{\text {th }}, 14^{\text {th }}, 21^{\text {st }}$ and $30^{\text {th }}$ days after the post-operative period. The results of the phytochemical prospecting of $P$. ramiflora extract demonstrated the major presence of phenolic compounds and flavonoids; the assessment of the inflammatory infiltrate on the $7^{\text {th }}$ day was higher on group Ext and Ext+gel when compared to group Control; on the 14th day control and Ext $(\mathrm{p}<0.05)$. The quantification of fibroblasts was higher on the $7^{\text {th }}$ day among the three treatments, control and $\operatorname{Ext~}(\mathrm{p}<0.05)$, on the $21^{\text {st }}$ day. Angiogenesis showed a higher number of vessels in Ext+gel group $(p<0.05)$ on the $7^{\text {th }}$ day; in Control, Ext and Ext+gel $(p<0.05)$ on the $14^{\text {th }}$ day; and Control and Ext $(\mathrm{p}<0.05)$ on the $21^{\text {st }}$ day. The histopathological results showed that the formulation Ext+gel was efficient in tissue reparation and decrease in inflammatory cells on the diabetic's animals.
\end{abstract}

Keywords: Diabetes mellitus, tissue repair, healing plants, flavonoids.

\begin{abstract}
Resumo
O gênero Pouteria apresenta várias aplicações terapêuticas e, dentre elas, grande potencial antiflamatório. Os efeitos do gel de Pouteria ramiflora sobre a cicatrização de feridas na pele de ratos diabéticos foram avaliados pela histomorfometria. A estreptozotocina foi administrada por via intraperitoneal em animais após jejum de 12 horas, a confirmação de indução da diabetes foi confirmada pelo índice glicêmico (> $\left.240 \mathrm{mg} \mathrm{dL}^{-1}\right)$. Foi realizada uma incisão no dorso do animal e foram criados 3 grupos de tratamento: controle (gel carbopol), extrato etanólico (Ext) e Gel + extrato etanólico à $2 \%$ (Ext+gel); a avaliação histopatológica foi realizada no $7^{\circ}$, $14^{\circ}, 21^{\circ}$ e $30^{\circ}$ dias após o período pós operatório. Os resultados da prospecção fitoquímica dos extratos de P. ramiflora demonstraram majoritariamente a presença de compostos fenólicos e flavonóides; o infiltrado inflamatório avaliado no $7^{0}$ dia foi maior para animais do grupo controle em relação aos grupos Ext $(p<0.05)$ e Ext+gel $2 \%(p<0.05)$; no $14^{\circ}$ dia 0 controle e $\operatorname{Exp}(\mathrm{p}<0.05)$ apresentaram aumento significativo dos infiltrados inflamatórios. A presença de fibroblastos foi elevada no $7^{\circ}$ dia em todos os tratamentos. O processo da angiogênese mostrou um maior número de vasos sanguíneos entre os grupos Ext e Ext+gel $(\mathrm{p}<0.05)$ no $7^{\circ}$ dia; no $14^{\circ}$ dia o grupo controle, Ext $(\mathrm{p}<0.05)$, Control e Ext+gel $(\mathrm{p}<0.05)$ apresentaram aumento de vascularização, e no $21^{\circ}$ dia apenas os grupos controle e Ext $(p<0.05)$. Os resultados histopatológicos mostraram que a formulação gel carbopol + extrato etanólico a $2 \%$ foi eficiente na reparação de tecidos e na diminuição de células inflamatórias nos animais diabéticos.
\end{abstract}

Palavras-chave: Diabetes mellitus, reparo tecidual, plantas cicatrizantes, flavonoides.

\section{Introduction}

Currently, diseases such as Diabetes mellitus (DM) are considered a global concern. In developing countries such as Brazil, this pathology occupies $4^{\text {th }}$ position in worldwide country rank of prevalence in 2014 (Ogurtsova et al., 2017) and affects 5.9\% of the Brazilian population (Borba et al., 2019).

The social and economic repercussions of DM lead to serious problems affecting the population, such as premature death, incapacity to work and the high costs for control and treatment of its complications (Costa et al., 2017). 
The most common cause of physical disabilities is the amputation of lower limbs (legs and/or feet) (ADA, 2019), caused by chronic ulcers that typically appear as a wound, triggering a series of cell and biochemical reactions in the body, with the aim of repairing the injured tissue (Schmidt et al., 2010).

Although the pharmaceutical industry makes available a variety of medications that may act in wound healing (Doughty and Sparks-DeFriese, 2012), alternative treatments are sought. However, in the absence of a definitive treatment, it is essential to carry out a therapy that can help with this healing, leading to the reconstitution and restoration of tissue integrity (Honório-França et al., 2008).

In this scenario, the use of extracts and products derived from medicinal plants with anti-inflammatory, antioxidant and antibacterial activities has raised great interest in relation to the innovation of therapeutic methods for the treatment of lesions in diabetic patients (Corrêa et al., 2013). In Brazil, due to the historical use of plants by traditional populations from the Cerrado and Pantanal regions (Lorenzi et al., 2002), there is a strong possibility that certain species have the potential for commercial use, in the treatment of this and other pathologies.

Among the folk medicine species that occur in the Cerrado and Pantanal regions, used to treat inflammations, skin rashes, ulcers and diabetes, for example, is the genus Pouteria (Souza et al., 2012). Specifically, Pouteria ramiflora (Mart.) Radlk (Sapotaceae) presents a range of extracts prepared from its leaves and roots (Braz et al., 2012). It has been already tested with efficacy in experimental models in the treatment of hyperlipidemia and obesity (Gomes, 2013) and neuroprotective effects against oxidative damage (Costa, 2014). The anti-inflammatory and oxidative effect is attributed to phenolic, flavonoid and triterpene compounds, commonly found in species of the genus (Silva et al., 2009).

Plant extracts associated with the Carbopol gel it is usual due the ability of this gel to acquire high viscosity at low concentration. The gel also has bioadhesive properties, is compatible with many excipients and actives and persist for a long time at the application site (Rechia, 2010).

Therefore, it is important to know the action and the different cell alterations that take place in the tissue repair process, using extracts from popularly used plants. Thus, the objective of this study is to evaluate the effects of ethanolic extract from Pouteria ramiflora leaves on the healing of skin wounds on diabetic rats, through morphological and histological analysis, and also to highlight the class of secondary metabolites present in the leaves.

\section{Material and Methods}

\subsection{Plant material}

Pouteria ramiflora leaves were collected from 13 matrices on $26^{\text {th }}$ July, 2013 , Region of Taboco $\left(20^{\circ} 29^{\prime} 79^{\prime \prime} S 55^{\circ} 48^{\prime} 7\right.$ "and $19^{\circ} 26^{\prime} 7.60$ "S $\left.55^{\circ} 00^{\prime} 2.78^{\prime \prime} \mathrm{O}\right)$, around 8:00 a.m. in the municipality of Corguinho, Mato Grosso do Sul, with the aid of pruning shears and aerial pruning shears. The material collected was packed in polyethylene bags, in the form of a moist chamber and transported to the Campo Grande - MS.

After the exclusion of old and/or damaged leaves, the plant material was dried at ambient temperature $\left(27^{\circ} \mathrm{C} \pm 2.0\right)$ and after that, it was fragmented using pruning shears and ground in an electrical mill (MARCONI ${ }^{\circledR}$, MA048). Subsequently, it was stored in a hermetically sealed Amber glass flask-ampoule, labeled and kept in the refrigerator until the preparation of the extracts.

\subsection{Obtaining the plant extract and Phytochemical Analysis}

To obtain the crude ethanol extract (Ext), the powder from the leaves ( $800 \mathrm{~g}$ ) was extracted with ethanol, first in diagnostic ultrasound (UNIDQUE ${ }^{\circledR}, 1450$ ) for 60 minutes, followed by 24 hours of static maceration, both at ambient temperature $\left(27^{\circ} \mathrm{C} \pm 2.0\right)$. This procedure was repeated until the plant medication depletion (30 days). The solvent used was evaporated in rotary evaporators (Tecnal ${ }^{\circledR}$, MA120), under reduced pressure, obtaining $32 \mathrm{~g}$ of crude extract.

The extract was subjected to classical phytochemical analysis (Harborne, 1984) executed in triplicate, with results compared and contrasted, including the change of color and precipitation. The intensities were classified as partial $( \pm=10 \%)$, low $(+=25 \%)$, moderately moderate $(++=50 \%)$, moderate $( \pm++=75 \%)$ and high intensity $(+++$ $=100 \%)$, besides negative $(-=0 \%)$ (Fontoura et al., 2015).

The contents of total phenols were determined (FT) by the Folin-Ciocalteu method, using Gallic acid (10 to $\left.350 \mathrm{mg} \mathrm{mL}^{-1}\right)$ as the standard ( $\mathrm{Y}=1.067 \mathrm{X}-0.004 \mathrm{R}^{2}=0.982$ ); The flavonoids (F) were evaluated by the aluminum chloride method and as standard, Quercetin ( $Y=0.633 \mathrm{x}$ $0.061 \mathrm{R}^{2}=0.999$ ) was used to construct a calibration curve, according to the methodology of Do et al. (2014).

\subsection{Animals}

Sixty Wistar lineage male rats (Rattus norvegicus: albinus, Rodentia,Mammalia)(200 to $250 \mathrm{~g}$ ) were used. They had been previously analyzed regarding general health conditions, and were all acquired from the Central Vivarium of the Uniderp University. The animals were randomly distributed into groups and kept in individual polypropylene cages, with a grid cover made of stainless steel, receiving ration and water ad libitum. Animals use protocol for experimentation was approved by the Ethics Committee on Animal Use of the executing institution (2953/2014).

\subsection{Diabetes induction}

Induction was performed through the administration of streptozotocin $\left(\operatorname{Sigma}^{\circledR}\right)$, intraperitoneally in a single dose of $50 \mathrm{mg} \mathrm{kg}^{-1}$ per body weight, dissolved in citrate buffer (0.01 M, pH 4.5) after 12-hour fasting (Ebaid et al., 2011). The blood glucose increase confirmation was measured by glycosometer (Accu-check ${ }^{\circledR}$ ) on the $7^{\text {th }}$ day after induction. Animals with a fasting glycemia index greater than $250 \mathrm{mg}$ $\mathrm{dl}^{-1}$ were considered hyperglycemic on this study.

\subsection{Surgical procedures}

The animals were anesthetized, with Ketamine (90 $\mathrm{mg} \mathrm{kg}^{-1}$ ) and Xylazine (10 $\mathrm{mg} \mathrm{kg}^{-1}$ ), and an area of 
approximately $8 \mathrm{~mm}$ was wounded with a metal punch. The induced lesions were treated according to the experimental groups.

\subsection{Gel preparation and experimental groups}

On the Control group, only the Gel Carbopol at 70\% (M. Cassab ${ }^{\circledR}$ ) was used; on the Ethanolic Ext (Ext) group, only the ethanolic crude extract was used; and on the Gel+ Ethanolic extract (Ext+gel), the extract at $2 \%$ incorporated into the vehicle at Gel Carbopol at 70\% (M. Cassab ${ }^{\circledR}$ ) was used (Ferreira, 2006).

\subsection{Euthanasia}

The animals were euthanized with Ketamine and Xylazine, and an anesthetics overdose was performed (ketamine $300 \mathrm{mg} / \mathrm{kg}+$ xylazine $30 \mathrm{mg} / \mathrm{kg}$ ). The cutaneous lesions were excised with a $0.5 \mathrm{~mm}$ margin from the surrounding healthy skin for histological plates preparation.

\subsection{Histological analysis}

The histological aspects assessment (inflammatory infiltrate, fibroblasts and angiogenesis) was adapted according to Garros et al. (2006) following the scale: (0) absent, (1) discrete, (2) moderate and (3) intense, for morphological and histological study. Samples were fixed in buffered $4.0 \%$ paraformaldehyde. Then, samples were embedded in paraffin blocks and sectioned in $5 \mu \mathrm{m}$-thick samples with a microtome (Microm HM320 ${ }^{\circledR}$ ). The resulting sections were stained with hematoxylin and eosin. The stained samples were examined using an optical microscope (Carl Zeiss ${ }^{\circledR}$ ). The slides stained were analyzed using the IMAGELAB software.

\section{Statistical Analysis}

The data were subjected to statistical analysis using the software Bioestat 5.0. The continuous variables were tested for normal distribution with Shapiro-Wilk. Differences among the analysed groups were investigated through Kruskal-Wallis test, with a significance level of $\mathrm{p}<0.05$, and the means were compared by DUNN's test (5\%).

\section{Results}

\subsection{Phytochemical analysis}

The Ext showed 10 classes of secondary metabolites with predominance of phenolic compounds and tannins with high intensity (frequency of $100 \%=+++$ ), followed by the sugar content, cardiac glycoside, saponins, triterpenes and steroids with a frequency of $50 \%$ and, less frequently, flavonoids and anthraquinones (Figure 1). The total phenols quantification indicated that for Ext these were $225.8 \pm 0.2 \mathrm{mg} \mathrm{g}^{-1}$ and the flavonoids $98.2 \pm 0.55 \mathrm{mg} \mathrm{g}^{-1}$.

\subsection{Evaluation of the healing process after 7, 14, 21 and} 30 days

\subsubsection{Microscopic evaluation after seven days}

The evaluations of aspects regarding the deep dermis (inflammatory infiltrate, fibroblasts and angiogenesis) indicated that the groups presented crust and dermis with granulation tissue with an intense quantity of inflammatory cells, remarkable presence of fibroblasts (f) and formation of blood vessels (bv) (Figure 2). In all treatments, the quantities of inflammatory cells (mainly macrophages) were similar and are probably associated with the influx

\section{Class of Secondary Metabolites}

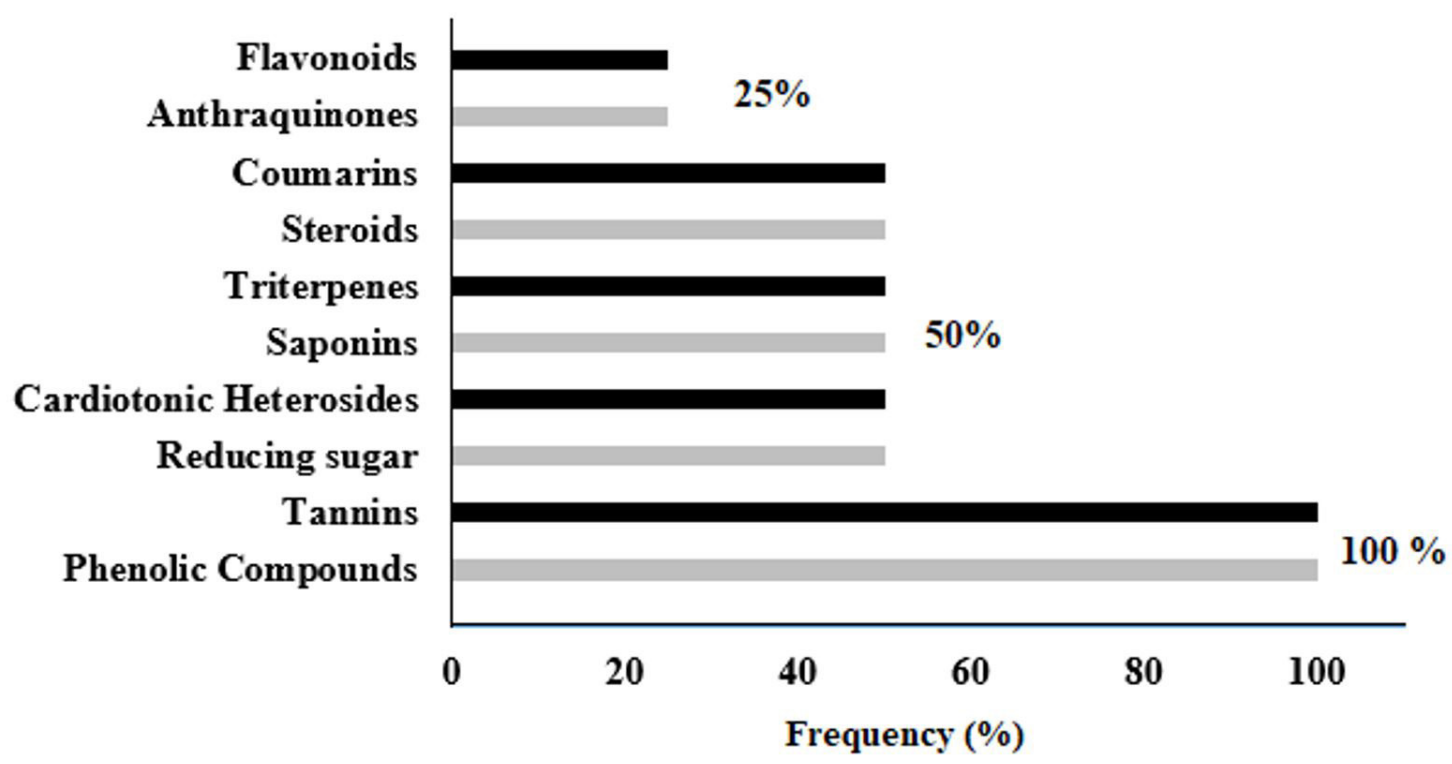

Figure 1. Chart of analysis phytochemical of Ethanolic extract of Pouteria ramiflora leaves, Campo Grande, 2016. Frequency = low $(+=$ $25 \%)$, moderately moderate $(++=50 \%)$ and high intensity ( $+++=100 \%)$, besides negative $(-=0 \%)$. 
of fibroblasts; however, there was the formation of a less thick crust in the animals in the Control and Ext+gel group.

Regarding the fibroblast analysis, the three groups presented important proliferation; however, the Ext group $(\mathrm{p}=0.0018)$ showed higher quantities in relation to the other groups, Control ( $\mathrm{p}=0.001$ ) and Ext+gel ( $\mathrm{p}=0.0012$ ) (Figure 3 ). Based on these results, diabetic experimental models change in the cells were evident. The angiogenesis quantitative analysis was verified by counting the number of blood vessels. The Ext group compared to the Ext+gel group ( $\mathrm{p}=0.0003$ ) showed greater formation of capillaries in $7^{\text {th }}$ day (Figure 3 ).

\subsubsection{Microscopic evaluation: 14 days}

After 14 days, the control group was observed with epidermis in process of organization, the deep dermis, organized granulation tissue and bundles of collagen fibers (Figure 4).

It can be observed that Ext+gel showed a reduction of the inflammatory infiltrate from the $7^{\text {th }}$ through the $14^{\text {th }}$ day, differently from the Control group ( $p=0.038$ ) (Figure 5), which showed a difference in relation to Ext and presented constant inflammatory infiltrate on the $7^{\text {th }}$ day.
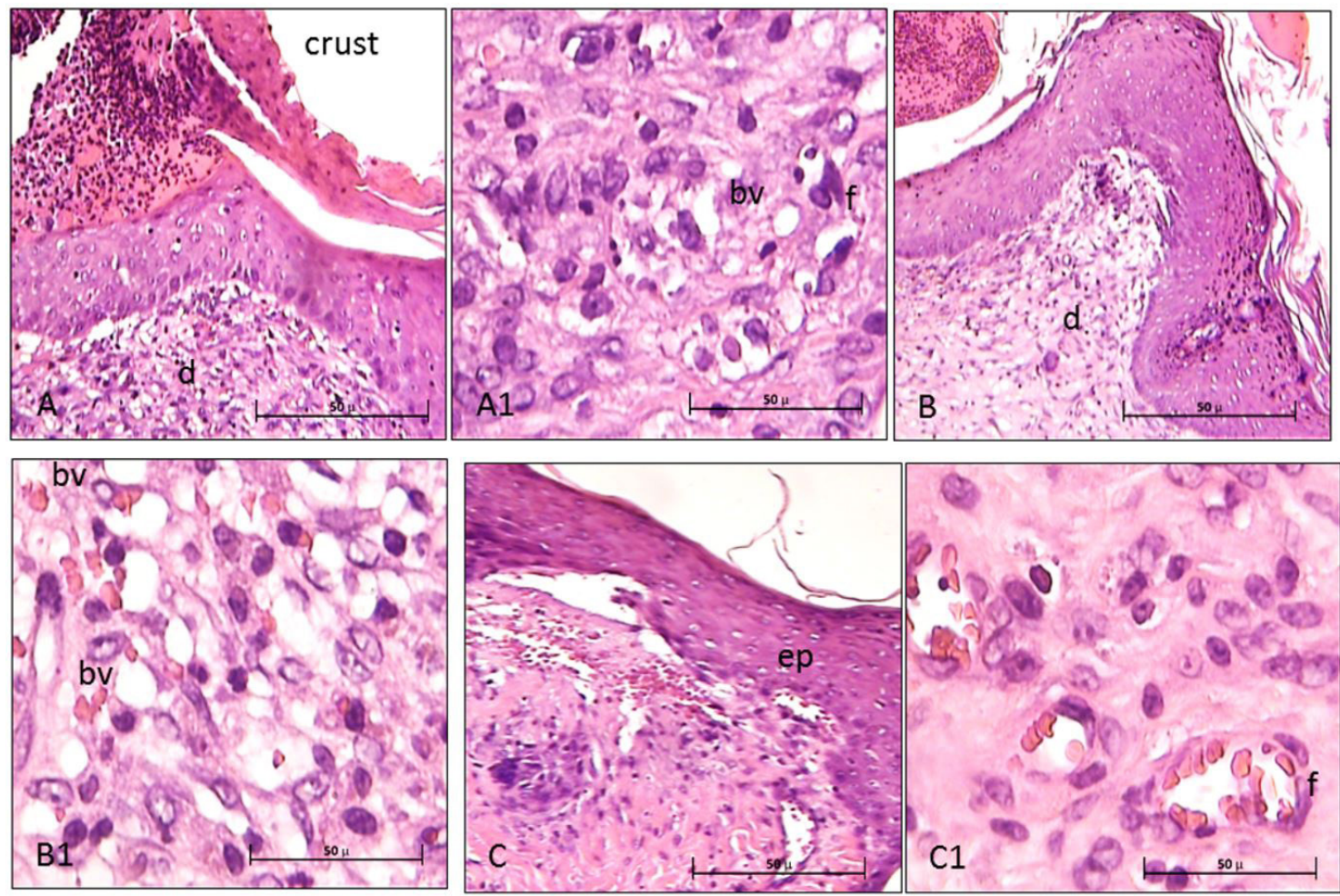

Figure 2. Photomicrograph of histological sections of diabetic rats' skin wounds of groups: Control, Ext and Ext+gel (A, B, C) at 7 days after injury of the skin wound (A1, B1, C1), crust, epidermis (ep); dermis (d) deep dermis with tissue granulation, fibroblasts (f); blood vessels (angiogenesis) (bv); (HE, 10 and 40x).
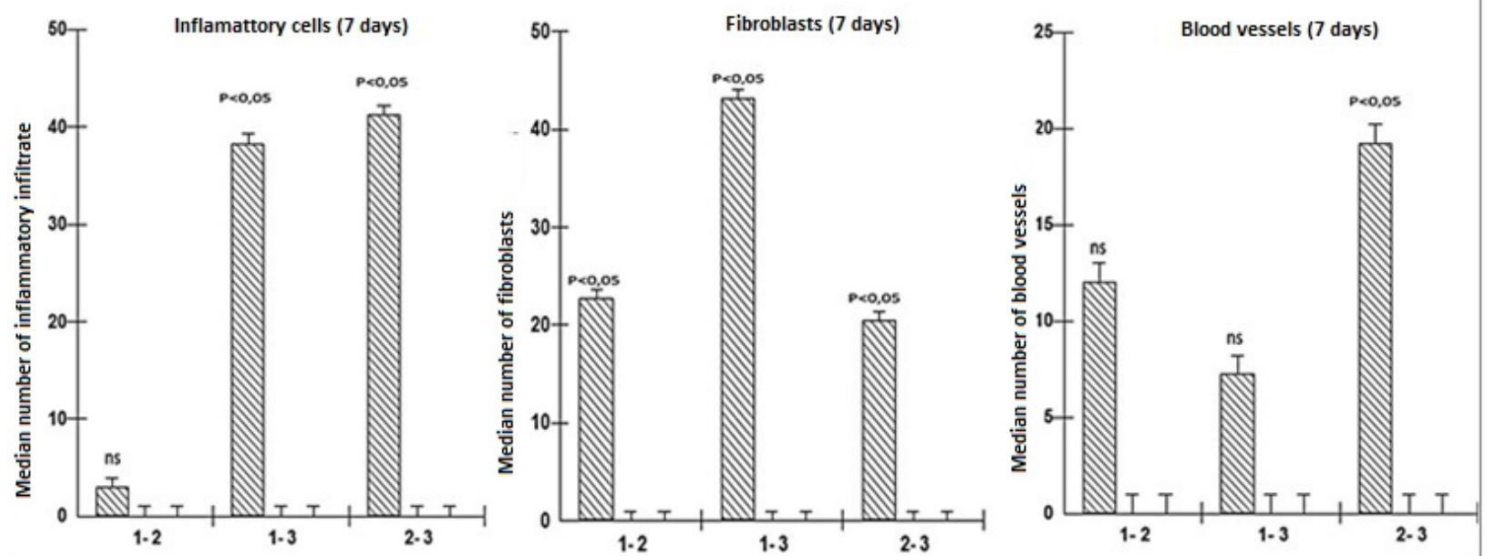

Figure 3. Quantification of inflammatory cells, fibroblasts, and angiogenesis (blood vessels) in diabetic animals' skin on groups: Control; Ext and Ext+gel, 7 days. ns (statistically not significant). DUNN's test $(\mathrm{P}=0.05)$. 

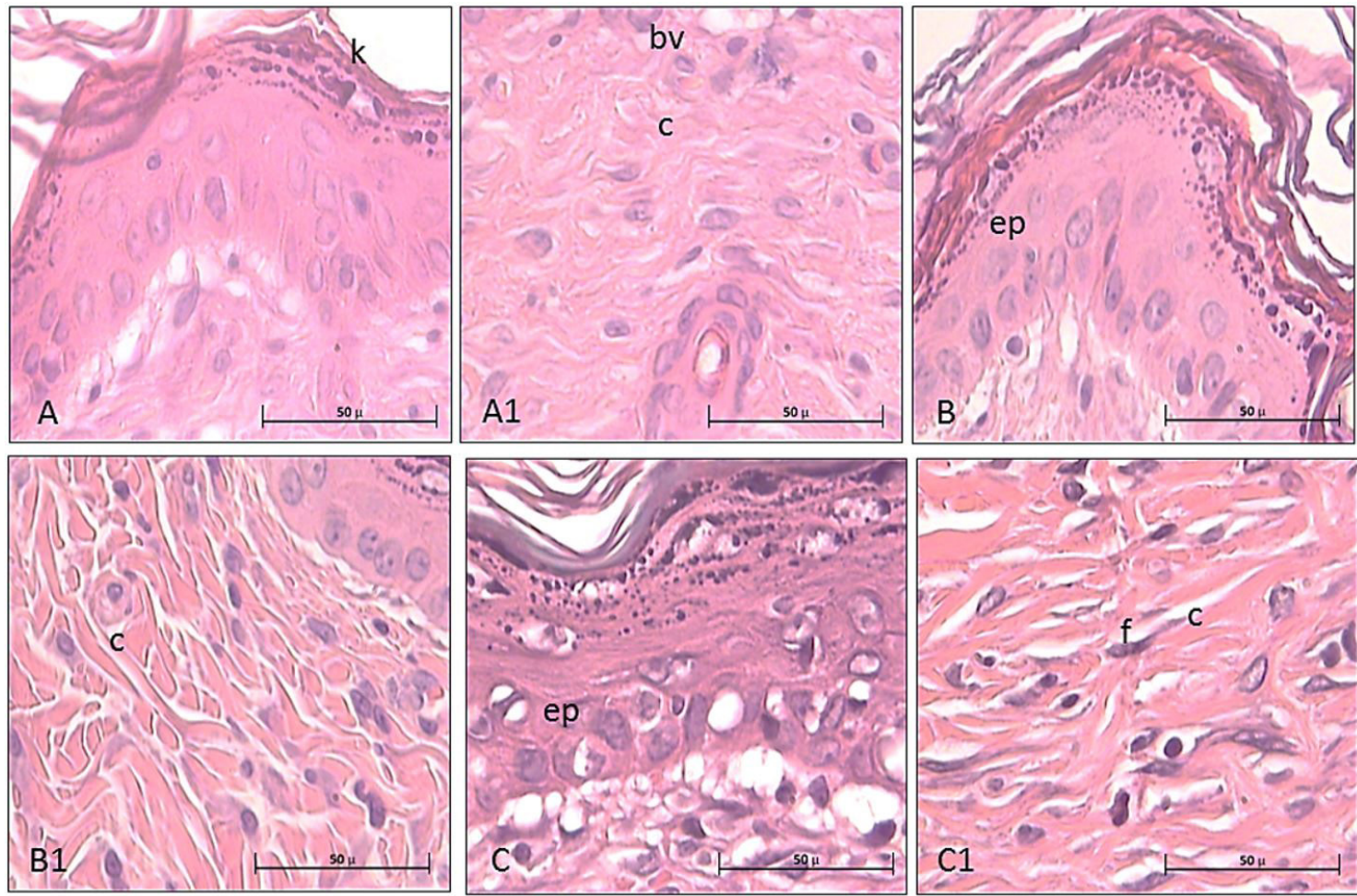

Figure 4. Photomicrograph of histological sections of diabetic rats' skin wounds. (A, A1), Control, Ext (B, B1) and Ext+gel (C, C1) to 14 days after injury of the skin wound. Epidermis (ep); keratin (k); fibroblast (f); collagen fibers (c); HE. Quantification of inflammatory cells, fibroblasts, and angiogenesis in diabetic animals' skin on groups: Control, Ext and Ext+gel, DUNN's test ( $\mathrm{P}=0.05)$.

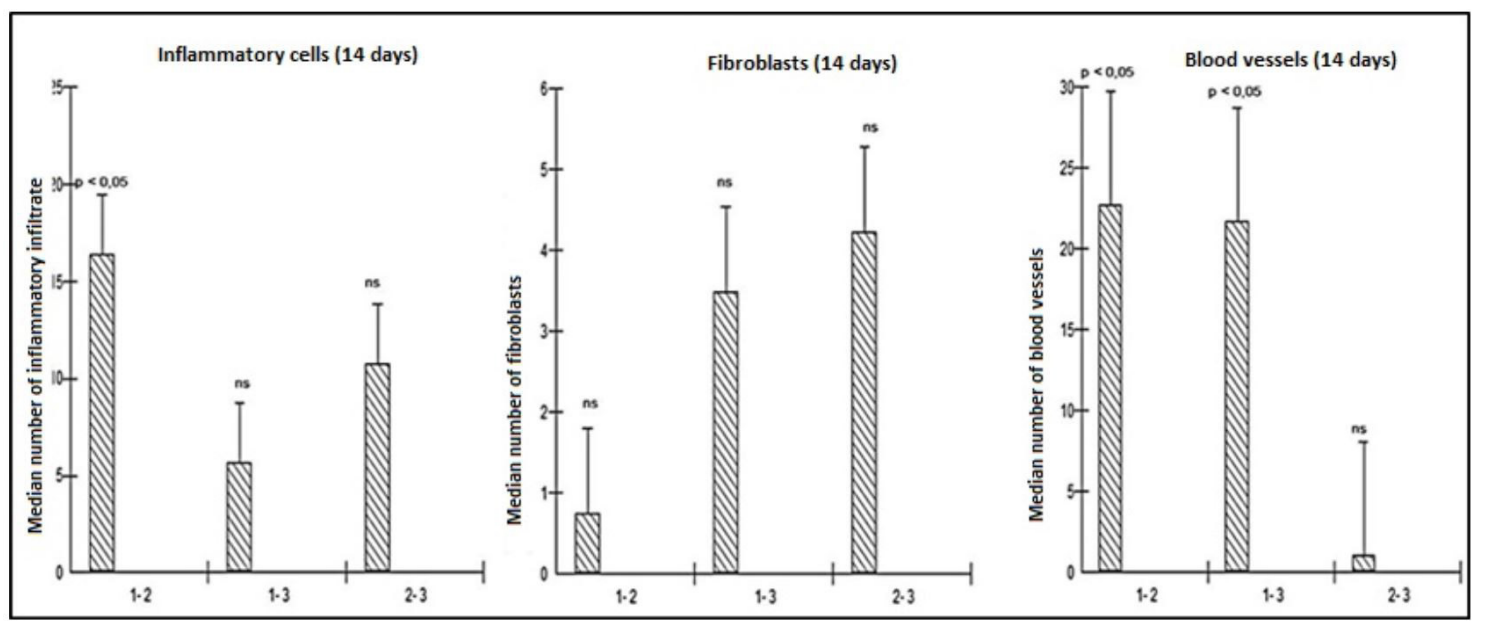

Figure 5. Quantification of inflammatory cells, fibroblasts, and angiogenesis (blood vessels) in diabetic animals' skin on groups: Control, Ext and Ext+gel, 14 days. ns (statistically not significant). DUNN's test ( $\mathrm{P}=0.05)$.

\subsubsection{Microscopic evaluation: 21 days}

In this period, the groups presented complete repithelialization of their wounds. In the same way, the dermis was observed to be in accordance with the final phase of the skin healing process, with a decrease of neovascularization and the presence of mononuclear cells. The marked presence of fibroblasts and collagen characterized the lesion remodeling process (Figure 6).

On the 21st day, the fibroblasts, mainly in Ext+gel showed the deposition of dense and wavy collagen, arranged neatly in the new tissue, unlike the control, which showed a significant difference in relation to $\operatorname{Ext}(\mathrm{p}=0.018)$ (Figure 7).

\subsubsection{Microscopic evaluation: 30 days}

The remodeling tissue is characterized by the reorganization of the extracellular matrix, with the architecture of the skin remodeled in an attempt to return to the normal tissue structure, a balance between formation of new collagen and degradation of old collagen. 

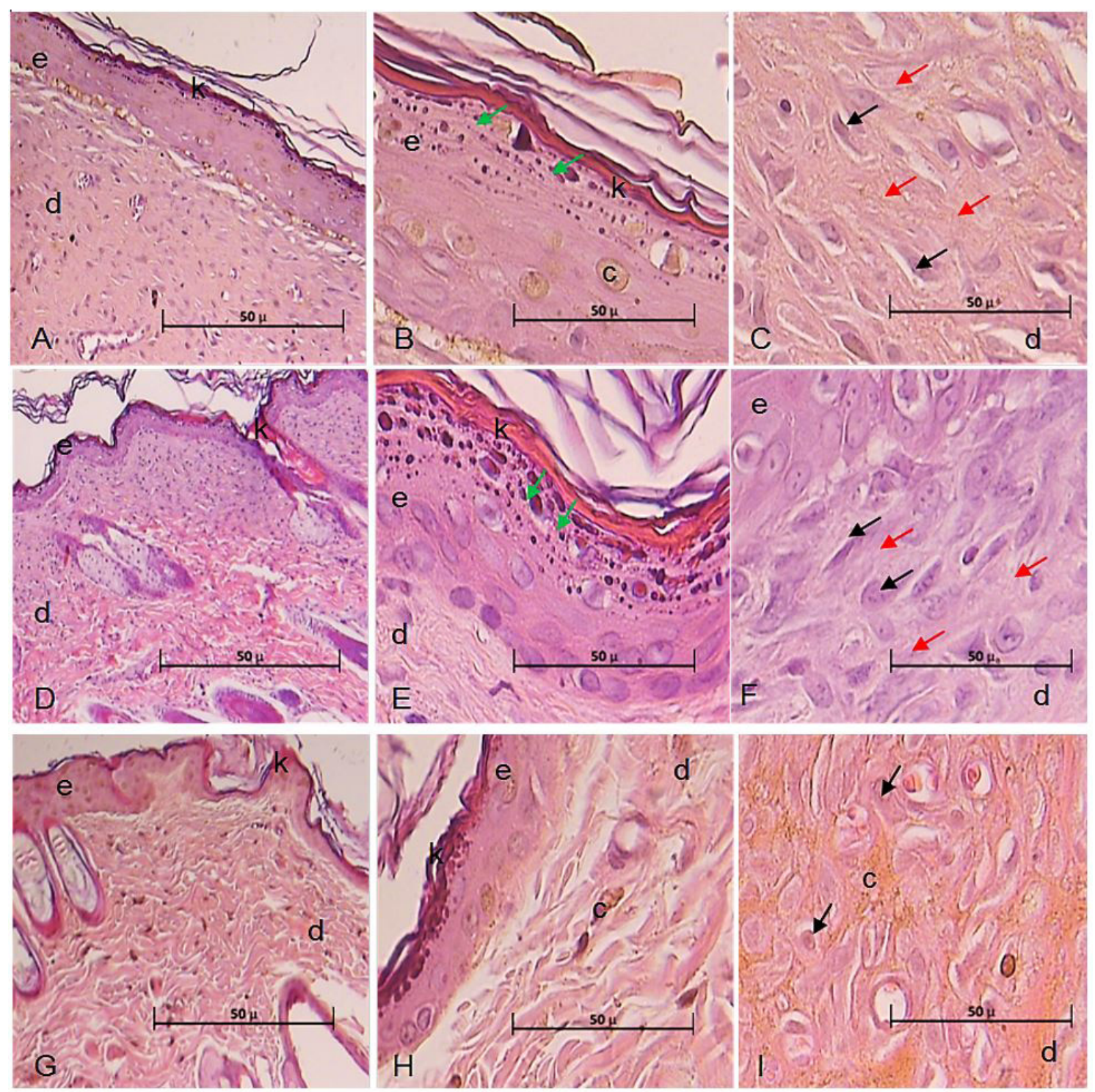

Figure 6. Photomicrograph of histological sections of rats' skin wounds of Control group (Carbopol) (A, B, and C), Ethanolic extract (Ext) (D, E, F) and Gel + Ethanolic extract 2\% (Ext+gel) (G, H, I) at 21 days after the skin wound injury (D, E, F). epidermis (e); keratin (k); dermis (d); carbopol (c); granular layer (green arrow); fibroblasts (black arrow); collagen (red arrow); HE.

Our findings demonstrated the evolution of the tissue remodeling process from the 14th day, with remarkable presence of epithelization layers and closure of the lesion; the groups did not show statistical differences when compared. As observed in Figure 8, the Ext+gel group exhibited greater organization of collagen fiber bundles and formation of skin appendages compared with the control group and with all the epidermal layers.

\section{Discussion}

A lack or excess of inflammatory response affects the healing process. In individuals that have Diabetes mellitus (DM), there is not only an increase in the glycemic index level, but also a decrease in permeability and in vascular flow, and this changes the tissue repair process evolution, influencing both the formation of collagen fibers and the injured tissue remodeling (Silva et al., 2011).

In some botanic species, phytochemical compounds are reported as having wound healing potential (Jain and Bari, 2010), because its prevents or delays the cellular necrosis occurrence (Chen et al., 2012). Medicinal plants show the ability to act in the anti-inflammatory action mechanisms (Coutinho et al., 2009), including antioxidant activity through the sequestering of free radicals, the activity of inflammatory cells, modulation of arachidonic acid metabolism, modulation of gene production and expression of pro-inflammatory molecules (Hernandes et al., 2010).

Phenolic and flavonoid compounds are attributed various pharmacological effects, such as 

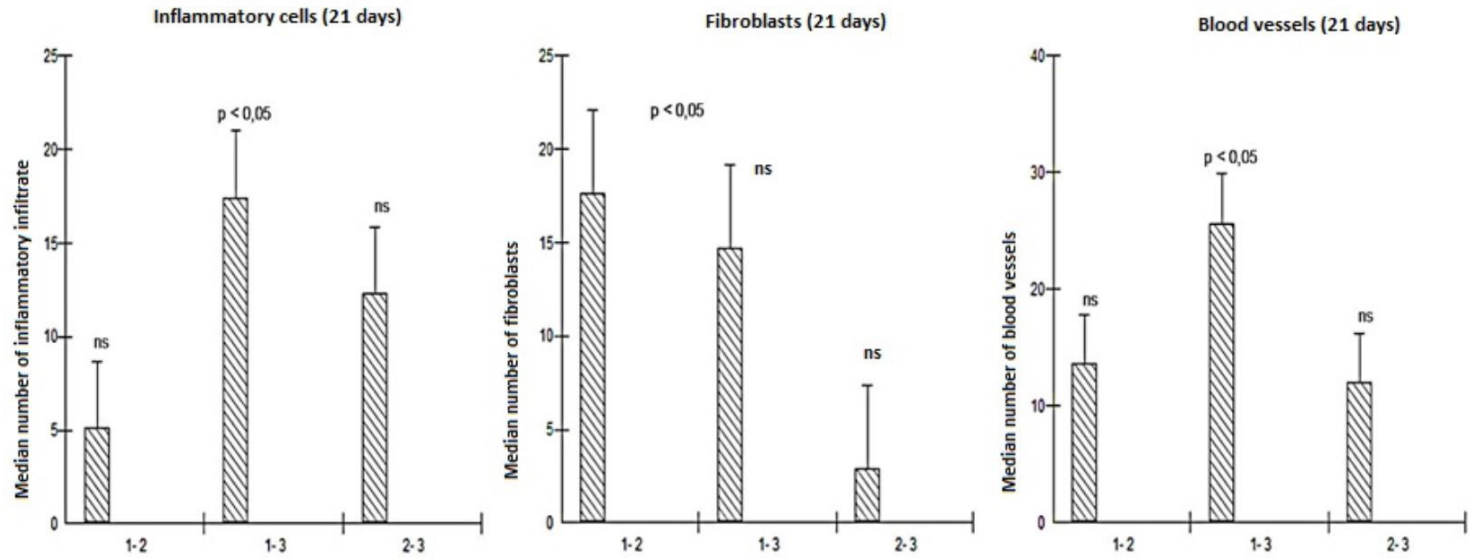

Figure 7. Quantification of inflammatory cells, fibroblasts, and angiogenesis (blood vessels) in diabetic animals' skin on groups: Control, Ethanolic extract (Ext) and Gel + Ethanolic extract 2\% (Ext+gel), 21 days. ns (statistically not significant). DUNN's test ( $\mathrm{p}=0.05)$.

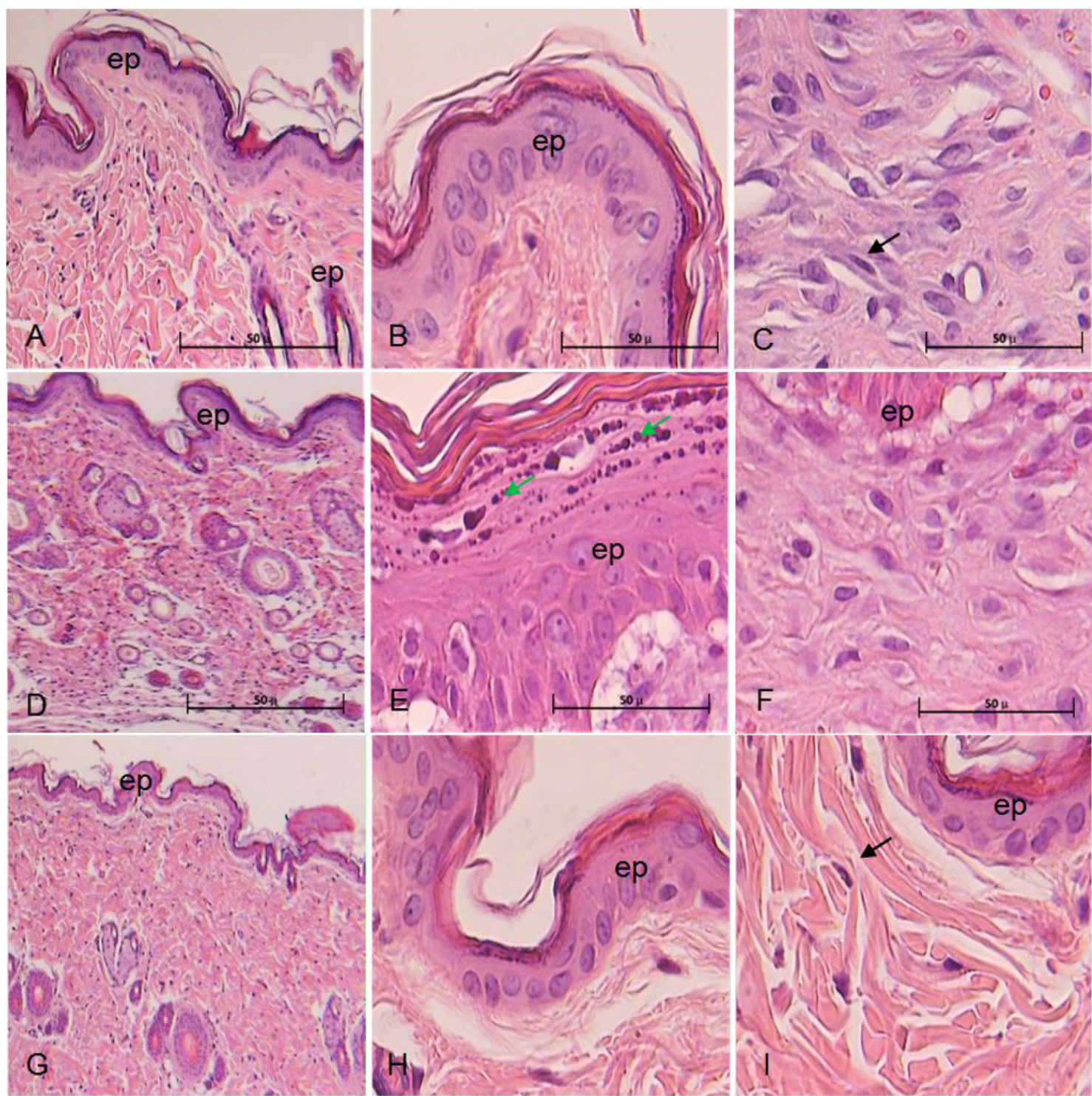

Figure 8. Photomicrograph of histological sections of rats' skin wounds of Control group (Carbopol) (A, B, and C), Ethanolic extract (Ext) (D, E, F) and Gel + Ethanolic extract 2\% (Ext+gel) (G, H, I) at 30 days after the skin wound injury (D, E, F). epidermis (ep); granular layer (green arrow); fibroblasts (black arrow). HE. 
antitumoral, antiulcerogenic, and anti-inflammatory (Coutinho et al., 2009), antibacterial and antifungal, antipyretic, anti-inflammatory and antiulcerogenic activity (Jain and Bari, 2010). The activity of flavonoids as antiinflammatories has been widely studied in vivo assays (Aragão Neto, 2013), and it is expected that in the future these compounds will be available as low-cost medications.

The phenolic, flavonoid and triterpene compounds are common phytochemicals in species of the genus Pouteria, including P. campechiana (Kunth) Baehni (Ma et al., 2004), P. caimito (Ruiz and Pav.) Radlk. (Canuto et al., 2010) and P. ramiflora (Oliveira et al., 2014).

$P$. torta and $P$. ramiflora leaves extracts feature high total phenols and flavonoids reported by Costa (2014). In this context, P. ramiflora ethanolic extract favored the treatment of hyperlipidemias and obesity, and has antioxidant potential (Condessa, 2011) and anti-inflammatory activity (Gomes, 2013). Besides that, this substances are attributed to have the potential for wound healing (Jain and Bari, 2010) and they are also reported to prevent or delay the cell necrosis onset. This occurs due to the fact that this group of substances have the ability to reduce lipid peroxidation and consequently improve vascularization, increasing the viability of fibrils of collagen, the resistance of the collagen fibers and boost the circulation, avoiding cell damage, as well as promoting DNA synthesis (Gurtner et al., 2008).

The healing process protective response forming the sheaths found in the lesions analysis is related to the tannins activity, which are proteins precipitators (Lima et al., 2010), forming a protective coating that promotes their repair, reducing the wound's permeability and exudation, favoring hemostasis after the injury (Silva et al., 2011). They also favor the proliferation of keratinocytes surrounding the injured region and an increase in the number of cross-links among the collagen fibers present in the extracellular matrix, assisting in the orientation of these fibers (Silva et al., 2011).

Our results exhibited from the $7^{\text {th }}$ to the $14^{\text {th }}$ days, suggested an Ext+gel group anti-inflammatory effect. The inflammatory infiltrate reduction is attributed to the flavonoid quercetin action reducing the inflammatory response by biochemical and pharmacological events (Batiha et al., 2020). These compounds can modulate the production of reactive oxygen species - ROS, in addition to other functions, such as degranulation and apoptosis (Moreira et al., 2009).

Despite the different number of mononuclear cells found between treated and postoperative groups, the inflammatory infiltrate reduction using medicinal plants with flavonoids cause proliferation and migration of a large quantities of fibroblasts (Castelo Branco Neto et al., 2006)

Currently, phytochemical properties are sought with potential to act on the inflammatory process with the inhibition of the production of pro-inflammatory mediators, containing the progression of tissue damage and combating possible infections, and their action is characterized by hemostasis and chemotaxis of neutrophils and monocytes (Isaac et al., 2010). The polymorphic nuclear cells appear at the time of injury and remain for a period of five days, being responsible for bacterial phagocytosis (Abbas et al., 2010).

Therefore, plant properties stand out because they encourage equal quantities of neutrophils in the initial periods, and it can be observed that the Ext+gel group also showed evolution. According to Mendonça and CoutinhoNetto (2009), the reorganization of the lesion repair process took place around the $12^{\text {th }}$ day and, according to Schultz et al. (2011), in this phase the proliferation of fibroblasts, collagen production, transformation of extracellular matrix in the provisional final matrix of collagen, and the total reepithelialization will take place (Alsarra, 2009).

The reepithelialization process found in the study at 30 days was equally affected by the treatments because the epithelium layers showed weak activity, corroborating descriptions by Leite (2014) that the migration of keratinocytes is initiated from a response to epidermal lesions, migration of keratinocytes from the edges to the center of the lesion, which in turn regulate and stimulate keratinocytes to migrate, proliferate and differentiate to form the epidermis (Velnar et al., 2009).

\section{Conclusion}

The ethanolic extract of $P$. ramiflora leaves has phenolic and flavonoid as the main components and the results showed that the groups treated with the ethanolic extract have an inhibitory effect on inflammatory cells, increasing the number of fibroblasts with organization of granulation tissue in groups 14 days.

\section{Acknowledgements}

The authors thank the National Council for Scientific and Technological Development (CNPq), the Center for Research in the Pantanal (CPP), the Support Foundation for the Development of Education, Science and Technology of the State of Mato Grosso do Sul (FUNDETEC), the National Institute of Wetlands (INAU) and Universidade AnhangueraUniderp, for the financial support and also FUNDECT for the Doctoral degree scholarship.

\section{References}

ABBAS, A.K., FAUSTO, N. and KUMAR, V., 2010. Patologia: bases patológicas das doenças. 8. ed. Rio de Janeiro: Elsevier/Medicina Nacional, 1480 p.

ALSARRA, I.A., 2009. Chitosan topical gel formulation in the management of burn wounds. International Journal of Biological Macromolecules, vol. 45, no. 1, pp. 16-21. http://dx.doi. org/10.1016/j.ijbiomac.2009.03.010. PMid:19447254.

AMERICAN DIABETES ASSOCIATION - ADA, 2019. Standards of medical care in diabetes-2019. Diabetes Care, vol. 42, no. 2, pp. 2.

ARAGÃO NETO, A.C., 2013. Avaliação da cicatrização de feridas cutâneas tratadas com hidrogel de policaju e quitosana associado a laser terapêutico. Recife: Universidade Federal de Pernambuco, 67 p. Dissertação de Mestrado em Bioquímica e Fisiologia.

BATIHA, G.E., BESHBISHY, A.M., IKRAM, M., MULLA, Z.S., EL-HACK, M.E.A., TAHA, A.E., ALGAMMAL, A.M. and ELEWA, Y.H.A., 2020. The pharmacological activity, biochemical properties, and pharmacokinetics of the major natural polyphenolic flavonoid: quercetin. Foods, vol. 9, no. 3, pp. 374. http://dx.doi.org/10.3390/ foods9030374. PMid:32210182. 
BORBA, A.K.D.O.T., ARRUDA, I.K.G., MARQUES, A.P.D.O., LEAL, M.C.C. and DINIZ, A.D.S., 2019. Conhecimento sobre o diabetes e atitude para o autocuidado de idosos na atenção primária à saúde. Ciencia \& Saude Coletiva, vol. 24, no. 1, pp. 125-136. http://dx.doi. org/10.1590/1413-81232018241.35052016. PMid:30698247.

BRAZ, E.M., MATTOS, P.P., SALIS, S.M. and CRISPIM, S.M.A., 2012. Manejo sustentável de florestas naturais do Pantanal. Colombo: Embrapa Florestas, pp. 8. Comunicado Técnico Embrapa, no. 302.

CANUTO, G.A.B., XAVIER, A.A.O., NEVES, L.C. and BENASSI, M.T., 2010. Caracterização físico-química de polpas de frutos da amazônia e sua correlação com a atividade anti-radical livre. Revista Brasileira de Fruticultura, vol. 32, no. 4, pp. 1196-1205. http://dx.doi.org/10.1590/S0100-29452010005000122.

CASTELO BRANCO NETO, M.L., RIBAS FILHO, J.M., MALAFAIA, O., DE OLIVEIRA FILHO, M.A., CZECZKO, N.G., AOKI, S., CUNHA, R., FONSECA, V.R., TEIXEIRA, H.M. and AGUIAR, L.R.F., 2006. Avaliação do extrato hidroalcoólico de Aroeira (Schinus terebinthifolius Raddi) no processo de cicatrização de feridas em pele de ratos. Acta Cirurgica Brasileira, vol. 21, no. 2, pp. 15-20. http://dx.doi.org/10.1590/s0102-86502006000800004.

CHEN, S.J., YEN, C.H., HUANG, Y.C., LEE, B.J., HSIA, S. and LIN, P.T., 2012. Relationships between inflammation, adiponectin, and oxidative stress in metabolic syndrome. PLoS One, vol. 7, no. 9 , pp. e45693. http://dx.doi.org/10.1371/journal.pone.0045693. PMid:23029185.

CONDESSA, M.B., 2011. Avaliação da atividade antioxidante e alelopática de plantas medicinais. Brasília: Universidade de Brasília, 120 p. Dissertação de Mestrado em Ciências da Saúde.

CORRÊA, A.C.L., HANS FILHO, G., DOURADO, D.M., MATIAS, R., SILVA, I.S. and SARRAGIOTTO, M.H., 2013. Healing effect of the ointment made of Equisetum pyramidale in the treatment of Cutaneous lesions in diabetic rats. Brazilian Archives of Biology and Technology, vol. 56, no. 3, pp. 377-382. http://dx.doi org/10.1590/S1516-89132013000300005.

COSTA, A.F., FLOR, L.S., CAMPOS, M.R., OLIVEIRA, A.F., COSTA, M.F., SILVA, R.S., LOBATO, L.C. and SCHRAMM, J.M., 2017. Carga do diabetes mellitus tipo 2 no Brasil. Cadernos de Saude Publica, vol. 33, no. 2, pp. e00197915. http://dx.doi.org/10.1590/0102311x00197915. PMid:28380131.

COSTA, D.L.M.G., 2014. Estudo químico e avaliação da atividade mutagênica dos extratos hidroalcoólicos das folhas de Pouteria torta e Pouteria ramiflora (Sapotaceae). Araraquara: Universidade Estadual Paulista, 144 p. Tese de Doutorado em Química.

COUTINHO, M.A.S., MUZITANO, M.F. and COSTA, S.S., 2009. Flavonoids: potential therapeutic agents for the inflammatory process. Revista Virtual de Química, vol. 1, no. 3, pp. 241-256. http://dx.doi.org/10.5935/1984-6835.20090024.

DO, Q.D., ANGKAWIJAYA, A.E., TRAN-NGUYEN, P.L., HUYNH, L.H., SOETAREDJO, F.E., ISMADJI, S. and JU, Y.H., 2014. Effect of extraction solvent on total phenol content, total flavonoid content, and antioxidant activity of Limnophila aromatica. Journal of Food and Drug Analysis, vol. 22, no. 3, pp. 296-302. http://dx.doi.org/10.1016/j.jfda.2013.11.001. PMid:28911418.

DOUGHTY, D.B. and SPARKS-DEFRIESE, B., 2012. Wound healing physiology. In: R.A. BRYANT and D.P. NIX, eds.. Maryland heights: acute and chronic wounds: current management concepts. USA: Mosby-Elsiever, pp. 63-82.

EBAID, H., SALEM, A., SAYED, A. and METWALLI, A., 2011. Whey protein enhances normal inflammatory responses during cutaneous wound healing in diabetic rats. Lipids in Health and Disease, vol. 10, no. 1, pp. 235. http://dx.doi.org/10.1186/1476511X-10-235. PMid:22168406.
FERREIRA, A.O., 2006. Formas farmacêuticas semi-sólidas. São Paulo: ANFAMAG, pp. 2-3. Sistema Nacional de Aperfeiçoamento e Monitoramento Magistral (SINAMM), módulo 4.

FONTOURA, F.M., MATIAS, R., LUDWIG, J., OLIVEIRA, A.K.M., BONO, J.A.M., MARTINS, P.F.R.B., CORSINO, J. and GUEDES, N.M.R., 2015. Seasonal effects and antifungal activity from bark chemical constituents of Sterculia apetala (Malvaceae) at Pantanal of Miranda, Mato Grosso do Sul, Brazil. Acta Amazonica, vol. 45, no. 3, pp. 283-292. http://dx.doi.org/10.1590/1809-4392201500011.

GARROS, I.C., CAMPOS, A.C.L., TÂMBARA, E.M., TENÓRIO, S.B., TORRES, O.J.M., AGULHAM, M.Â., ARAÚJO, A.C.F., SANTIS-ISOLAN, P.M.B., OLIVEIRA, R.M. and ARRUDA, E.C.M., 2006. Extrato de Passiflora edulis na cicatrização de feridas cutâneas abertas em ratos: estudo morfológico e histológico. Acta Cirurgica Brasileira, vol. 21, no. 3, suppl. 3, pp. 55-65. http://dx.doi.org/10.1590/ S0102-86502006000900009.

GOMES, P.D.M.F., 2013. Atividade biológica do extrato etanólico das folhas de Pouteria ramiflora (Mart.) Radlh e estudo químico. Campo Grande: Universidade Anhanguera Uniderp, 89 p. Dissertação de Mestrado em Meio Ambiente e Desenvolvimento Regional.

GURTNER, G.C., WERNER, S., BARRANDON, Y. and LONGAKER, M.T., 2008. Wound repair and regeneration. Nature, vol. 453, no. 7193, pp. 314-321. http://dx.doi.org/10.1038/nature07039. PMid:18480812.

HARBORNE, J., 1984. Methods of plant analysis. In: J.B. HARBORNE, ed. Phytochemical methods. Dordrecht: Springer, pp. 1-36. http://dx.doi.org/10.1007/978-94-009-5570-7_1.

HERNANDES, L., PEREIRA, L.M.S., PALAZZO, F. and MELLO, J.C.P., 2010. Wound-healing evaluation of ointment from stryphnodendron adstringens (barbatimão) in rat skin. Brazilian Journal of Pharmaceutical Sciences, vol. 46, no. 3, pp. 431-436. http:// dx.doi.org/10.1590/S1984-82502010000300005.

HONÓRIO-FRANÇA, A.C., MARINS, C.M.F., BOLDRINI, F. and FRANÇA, E.L., 2008. Evaluation of hypoglicemic activity and healing of extract from amongst bark of "Quina do Cerrado" (Strychnos pseudoquina ST. HILL). Acta Cirurgica Brasileira, vol. 23, no. 6, pp. 504-510. http://dx.doi.org/10.1590/S0102-86502008000600007. PMid:19030749.

ISAAC, C., LADEIRA, P.R.S., RÊGO, F.M.P., ALDUNATE, J.C.B. and FERREIRA, M.C, 2010. Processo de cura das feridas: cicatrização fisiológica. Revista de Medicina (São Paulo), vol. 89, no. 3/4, pp. 125. http://dx.doi.org/10.11606/issn.1679-9836.v89i3/4p125-131.

JAIN, P.S. and BARI, S.B., 2010. Evaluation of wound healing effect of petroleum ether and methanolic extract of Abelmoschus manihot (L.) Medik., Malvaceae, and Wrightia tinctoria R. Br., Apocynaceae, in rats. Brazilian Journal of Pharmacognosy, vol. 20, no. 5, pp. 756-761. http://dx.doi.org/10.1590/S0102-695X2010005000009.

LEITE, S.N., 2014. Fototerapia como estímulo à cicatrização de úlceras cutâneas em ratos frente ao estresse oxidativo experimental. São Paulo: Universidade de São Paulo, 126 p. Tese de Doutorado em Bioengenharia.

LIMA, C.R.O., SOUZA, L.A., HELOU, J.B., ALMEIDA E SILVA, J. and CAETANO, L.B., 2010. Caracterização dos metabólitos secundários do barbatimão. In: L.A.F. SILVA, D. EURIDES, J.R. PAULA, C.R.O.LIMA and M.I. MOURA. Manual do barbatimão. Goiânia: Kelps, pp. 61-68.

LORENZI, H., MATOS, F.J. and FRANCISCO, J.M., 2002. Plantas medicinais no Brasil: nativas e exóticas. 2. ed. Nova Odessa: Instituto Plantarum, 576 p.

MA, J., YANG, H., BASILE, M.J. and KENNELLY, E.J., 2004. Analysis of polyphenolic antioxidants from the fruits of three Pouteria species by selected ion monitoring liquid chromatography-mass spectrometry. Journal of Agricultural and Food Chemistry, vol. 52, no. 19, pp. 5873-5878. http://dx.doi.org/10.1021/jf049950k. PMid: 15366835. 
MENDONÇA, R.J. and COUTINHO-NETTO, J., 2009. Aspectos celulares da cicatrização. Anais Brasileiros de Dermatologia, vol. 84, no. 3, pp. 257-262. http://dx.doi.org/10.1590/S036505962009000300007 . PMid:19668939.

MOREIRA, R.O., AMÂNCIO, A.P.R.L., BRUM, H.R., VASCONCELOS, D.L. and NASCIMENTO, G.F., 2009. Sintomas depressivos e qualidade de vida em pacientes diabéticos tipo $2 \mathrm{com}$ polineuropatia distal diabética. Arquivos Brasileiros de Endocrinologia \& Metabologia, vol. 53, no. 9, pp. 1103-1111. http://dx.doi.org/10.1590/S0004-27302009000900007. PMid:20126868.

OGURTSOVA, K., DA ROCHA FERNANDES, J.D., HUANG, Y., LINNENKAMP, U., GUARIGUATA, L., CHO, N.H., CAVAN, D., SHAW, J.E. and MAKAROFF, L.E., 2017. IDF Diabetes Atlas: global estimates for the prevalence of diabetes for 2015 and 2040. Diabetes Research and Clinical Practice, vol. 128, pp. 40-50. http://dx.doi.org/10.1016/j.diabres.2017.03.024. PMid:28437734.

OLIVEIRA, A.K.M., PEREIRA, K.C.L., MULLER, J.A.I. and MATIAS, R., 2014. Análise fitoquímica e potencial alelopático das cascas de Pouteria ramiflora na germinação de alface. Horticultura Brasileira, vol. 32, no. 1, pp. 41-47. http://dx.doi.org/10.1590/ S0102-05362014000100007.

RECHIA, L.M., 2010. Desenvolvimento e avaliação da estabilidade de gel a base de extrato de Melissa Officinalis L. Florianópolis: Universidade Federal de Santa Catarina, 128 p. Dissertação de Mestrado em Ciências Farmacêuticas.
SCHMIDT, M.I., DUNCAN, B.B., STEVENS, A., LUFT, V., ISER, B.P.M., MOURA, L. and MALTA, D.C., 2010. Doenças Crônicas não transmissíveis no Brasil: mortalidade, morbidade e fatores de risco. In: MINISTÉRIO DA SAÚDE, ed. Saúde Brasil 2009: uma análise da situação de saúde e da Agenda Nacional e Internacional de Prioridades em Saúde. Brasília: Ministério da Saúde, pp. 111-135.

SCHULTZ, G.S., DAVIDSON,J.M., KIRSNER, R.S., BORNSTEIN, P.and HERMAN, I.M., 2011. Dynamic reciprocity in the wound microenvironment. Wound Repair and Regeneration, vol. 19, no. 2, pp. 134-148. http:// dx.doi.org/10.1111/j.1524-475X.2011.00673.x. PMid:21362080.

SILVA, C.A.M., SIMEONI, L.A. and SILVEIRA, D., 2009. Genus Pouteria: chemistry and biological activity. Brazilian Journal of Pharmacognosy, vol. 19, no. 2, pp. 501-509. http://dx.doi. org/10.1590/S0102-695X2009000300025.

SILVA, M., LIMA, W.G., SILVA, M.E. and PEDROSA, M.L., 2011. Efeito da estreptozotocina sobre os perfis glicêmico e lipídico e o estresse oxidativo em hamsters. Arquivos Brasileiros de Endocrinologia \& Metabologia, vol. 55, no. 1, pp. 46-53. http:// dx.doi.org/10.1590/S0004-27302011000100006. PMid:21468519.

SOUZA, P.M., SALES, P.M., SIMEONI, L.A., SILVA, E.C., SILVEIRA, D. and MAGALHÃES, P.O., 2012. Inhibitory activity of $\alpha$-amylase and $\alpha$-glucosidase by plant extracts from the Brazilian cerrado. Planta Medica, vol. 78, no. 4, pp. 393-399. http://dx.doi. org/10.1055/s-0031-1280404. PMid:22134849.

VELNAR, T., BAILEY, T. and SMRKOLJ, V., 2009. The wound healing process: an overview of the cellular and molecular mechanisms. The Journal of International Medical Research, vol.37, no. 5, pp. 1528-1542. http://dx.doi.org/10.1177/147323000903700531. PMid:19930861. 